\title{
OPEN Paleotemperature record of the Middle Devonian Kačák Episode
}

\author{
Thomas J. Suttner ${ }^{1 凶}$, Erika Kido ${ }^{1}$, Michael M. Joachimski ${ }^{2}$, Stanislava Vodrážková ${ }^{3}$, \\ Monica Pondrelli ${ }^{4}$, Carlo Corradini ${ }^{5}$, Maria G. Corriga ${ }^{6}$, Luca Simonetto ${ }^{6} \&$ Michal Kubajko ${ }^{3}$
}

The Middle Devonian Epoch, 393-383 million years ago, is known for a peak in diversity and highest latitudinal distribution of coral and stromatoporoid reefs. About 388 million years ago, during the late Eifelian and earliest Givetian, climax conditions were interrupted by the polyphased Kačák Episode, a short-lived period of marine dys-/anoxia associated with climate warming that lasted less than $\mathbf{5 0 0} \mathrm{kyr}$. Reconstruction of the seawater temperature contributes to a better understanding of the climate conditions marine biota were exposed to during the event interval. To date, conodont apatite-based paleotemperatures across the Eifelian-Givetian boundary interval have been published from Belarus, France, Germany and North America (10-36 $\mathrm{S}$ paleolatitude). Here we provide new $\delta^{18} \mathrm{O}_{\text {apatite }}$ data from the Carnic Alps (Austria, Italy) and the Prague Synform (Czech Republic). For better approximation of the paleotemperature record across the Kačák Episode, a latitude-dependent correction for Middle Devonian seawater $\delta^{18} \mathrm{O}$ is applied. Because $\delta^{18} \mathrm{O}_{\text {apatite }}$ data from shallow marine sections are influenced by regional salinity variations, calculated mean sea surface temperatures (SST) are restricted to more open marine settings $\left(22-34^{\circ} \mathrm{S}\right.$ paleolatitude). Water temperatures reach $\sim 34^{\circ} \mathrm{C}$ in the Prague Synform and $~ 33^{\circ} \mathrm{C}$ in the Carnic Alps and suggest that SSTs of the southern hemisphere low latitudes were $\sim 6^{\circ} \mathrm{C}$ higher than previously assumed for this time interval.

The Middle Devonian Kačák Episode ${ }^{1}$ is known as a minor global extinction event associated with a eustatic sea level rise ${ }^{2}$. The event interval, first recognized as significant lithological change from the Choteč Limestone to the Kačák Shale within the Prague Synform (Czech Republic), is characterized by global occurrence of bottomwater dys-/anoxia and expanded deposition of black shales ${ }^{1,3-9}$. The Kačák Episode was divided into two event intervals, named late Eifelian 1 Event (LEE1) and late Eifelian 2 Event (LEE2), reflecting its polyphased nature ${ }^{1,10}$. Although the Kačák Episode was initiated by black shale deposition during the late Eifelian about 388 million years ago (uppermost part of the kockelianus conodont Biozone), it did not terminate at the Eifelian-Givetian boundary but reached into the earliest Givetian (hemiansatus conodont Biozone) ${ }^{10,11}$. At the Eifelian/Givetian GSSP (Global Stratotype Section and Point) at Mech Irdane (Morocco), the Kačák Episode is temporally constrained to a relatively short interval of about $370 \mathrm{kyr}^{12,13}$.

Biodiversity analysis has shown that mainly ammonoids $s^{5,14-16}$, conodonts ${ }^{10,11,17,18}$ and trilobites ${ }^{19,20}$ suffered from a certain taxonomic loss. However, it appears that extinction was not the main response of faunal communities to environmental changes but rather habitat tracking and speciation events. Several groups even produced new taxa, e.g., planktonic dacryoconarid tentaculitids like Nowakia otomari occurred with the onset of LEE $1^{21}$. An increased intraspecific variability is observed among some polygnathid and icriodontid conodont taxa ${ }^{10,11,18,22}$. Additionally, the bathymetric changes coherent with the late Eifelian eustatic sea level rise effected the paleogeographic distribution of benthic marine organisms ${ }^{23,24}$. Some of Rhenish-type brachiopod and trilobite taxa migrated from southern Euramerica (Ardenne area) to the northern shelf of Gondwana (Prague Synform) during the latest Eifelian ${ }^{24}$. Similar migration patterns are seen among rugose corals along the western Euramerican shallow shelf, where cosmopolitan taxa of the Old World Realm invaded and replaced the endemic coral community of the East Americas Realm ${ }^{23}$. Probably, not only because previously existing topographic barriers were removed and shelf areals broadened, but also because the inferred global warming allowed/forced extension of the latitudinal distribution of temperature-dependent taxa.

New insights about the late Eifelian global warming period known as the Kačák Episode were generated by analysis of latitudinally dependent paleotemperature patterns reconstructed from conodont apatite. So far,

${ }^{1}$ Department of Geological and Environmental Sciences, Appalachian State University, Boone, NC 28608-2006, USA. ${ }^{2}$ GeoZentrum Nordbayern, Friedrich-Alexander Universität Erlangen-Nürnberg, Schlossgarten 5, 91054 Erlangen, Germany. ${ }^{3}$ Czech Geological Survey, Geologická 6, 15200 Prague 5, Czech Republic. ${ }^{4}$ IRSPS, Università d'Annunzio, viale Pindaro 42, 65127 Pescara, Italy. ${ }^{5}$ Dipartimento di Matematica e Geoscienze, Università degli Studi di Trieste, Via Weiss 2, 34128 Trieste, Italy. ${ }^{6}$ Museo Friulano di Storia Naturale, via Sabbadini 22-32, 33100 Udine, Italy. ${ }^{\varpi}$ email: suttnertj@appstate.edu 


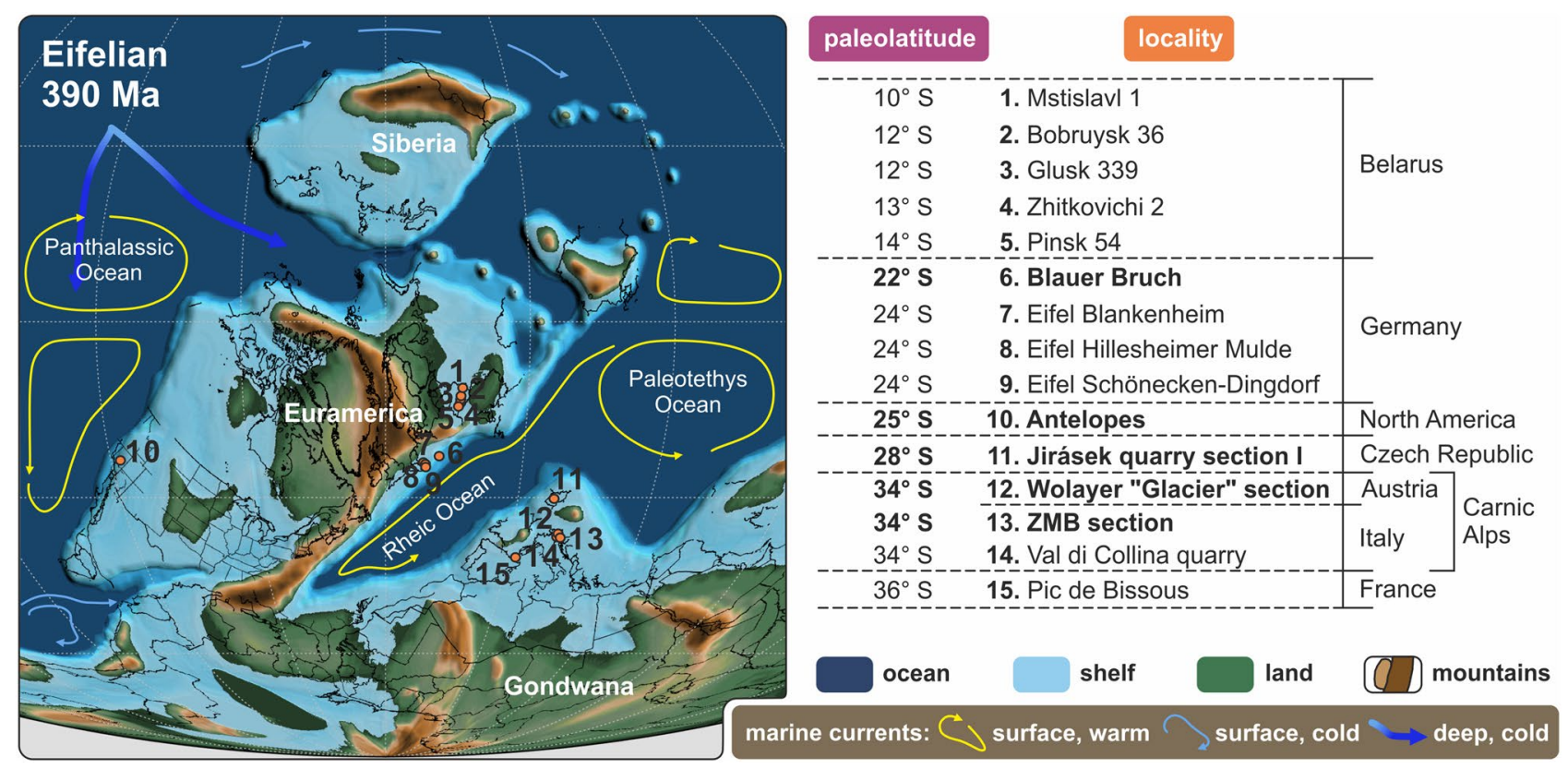

Figure 1. Paleolatitudinal position of published and newly studied localities during the Middle Devonian (late Eifelian to earliest Givetian). Localities reflecting more open marine conditions are marked in bold. Eifelian paleogeographic reconstruction modified after Scotese ${ }^{33}$.

paleotemperatures were published from southern hemisphere low latitudes between $10^{\circ}$ and $36^{\circ} \mathrm{S}$ for localities in France (Pic de Bissous) ${ }^{25}$ and Germany (Blankenheim, Hillesheimer Mulde, Schönecken-Dingdorf and Blauer Bruch $)^{25,26}$. Additional data from Nevada, USA (northern Antelope mountains) documented a negative shift in the $\delta^{18} \mathrm{O}_{\text {apatite }}$ during the onset of the LEE1 (upper part of the kockelianus Biozone) ${ }^{27}$, and more recently, paleotemperature reconstructions from Belarus were provided for the latest Eifelian interval (ensensis Biozone) ${ }^{28,29}$.

Here we discuss late Eifelian to earliest Givetian paleotemperature estimates based on new $\delta^{18} \mathrm{O}_{\text {apatite }}$ data from a shallow to deeper water transect within the Carnic Alps (Austria, Italy) and an offshore section from the Prague Synform (Czech Republic). Together with palaeotemperature estimates from other localities within the Rheic Ocean and the North American shelf, mean sea surface temperatures for each region and biozone are calculated and compared (Fig. 1). Because paleotemperature estimates from shallow marine localities appear to be biased by varying salinities, the temperature record across the Kačák Episode is limited to more open marine deposits of the Carnic Alps.

Keeping in mind that Middle Devonian coral-stromatoporoid reefs showed a remarkable wide latitudinal dispersal of up to $50^{\circ}$ on either hemisphere with an acme in diversity just after the Kaćák Episode during the early and middle Givetian ( 387-382 million years ago $)^{30-32}$, only a detailed study of the event interval can show how the marine biosphere dealt with environmental changes at that time. Estimation of paleotemperatures across the event interval contributes to uncover critical temperatures and to identify ecological limits of climate sensitive low latitude communities.

\section{Geological settings}

The Carnic Alps, part of the Proto-Alps ${ }^{34}$, were situated on the northern peri-Gondwana shelf located around $34^{\circ}$ $S$ during the Devonian. Today the area forms a more than $2000 \mathrm{~m}$ high mountain chain along the Austro-Italian border with Middle Devonian rocks well-exposed between the Biegengebirge in the west and Mount Osternig in the east (Fig. 2A,B) ${ }^{35}$. Coeval sections from different bathymetric settings were investigated (Fig. 2B). The section studied in the Val di Collina quarry (N46 35' 49.07"; E12 $\left.{ }^{\circ} 55^{\prime} 29.22^{\prime \prime}\right)$ consists of back reef and reef environments belonging to the Spinotti and Kellergrat formations, respectively. The Zuc di Malaseit Basso (ZMB) section (N46 ${ }^{\circ}$ 33' 19.06"; E13 11' 10.6") was deposited within a distal slope setting of the Hoher Trieb Formation, while the Wolayer "Glacier" section (N46 36' 46.56"; E12 ${ }^{\circ} 52^{\prime} 33.66^{\prime \prime}$ ) is represented by condensed pelagic deposits of the Valentin Formation. These sections were correlated using high-resolution conodont biostratigraphy ${ }^{11}$.

The Middle Devonian Srbsko Formation in the Prague Synform (part of the Bohemian Massif) is generally developed in siliciclastic facies ${ }^{36}$ and was located around $28^{\circ} \mathrm{S}$. The studied Jirásek quarry section I (N49 $54^{\prime}$ 50.2"; E14 $\left.04^{\prime} 34.2^{\prime \prime}\right)$ represents a unique section where the stratigraphic equivalent of the Kaćák Member of the Srbsko Formation is developed in carbonate facies. The so-called Upper Dark Interval (UDI), exposes a dark gray thin-bedded to nodular limestone interval representing the uppermost portion of the Acanthopyge Limestone (Choteč Formation, Fig. 2A,C) ${ }^{37}$. Upper Eifelian deposits are unconformably overlain by a limestone breccia, wherefore the middle/upper? part of the ensensis Biozone within the UDI was probably reworked ${ }^{18}$. 

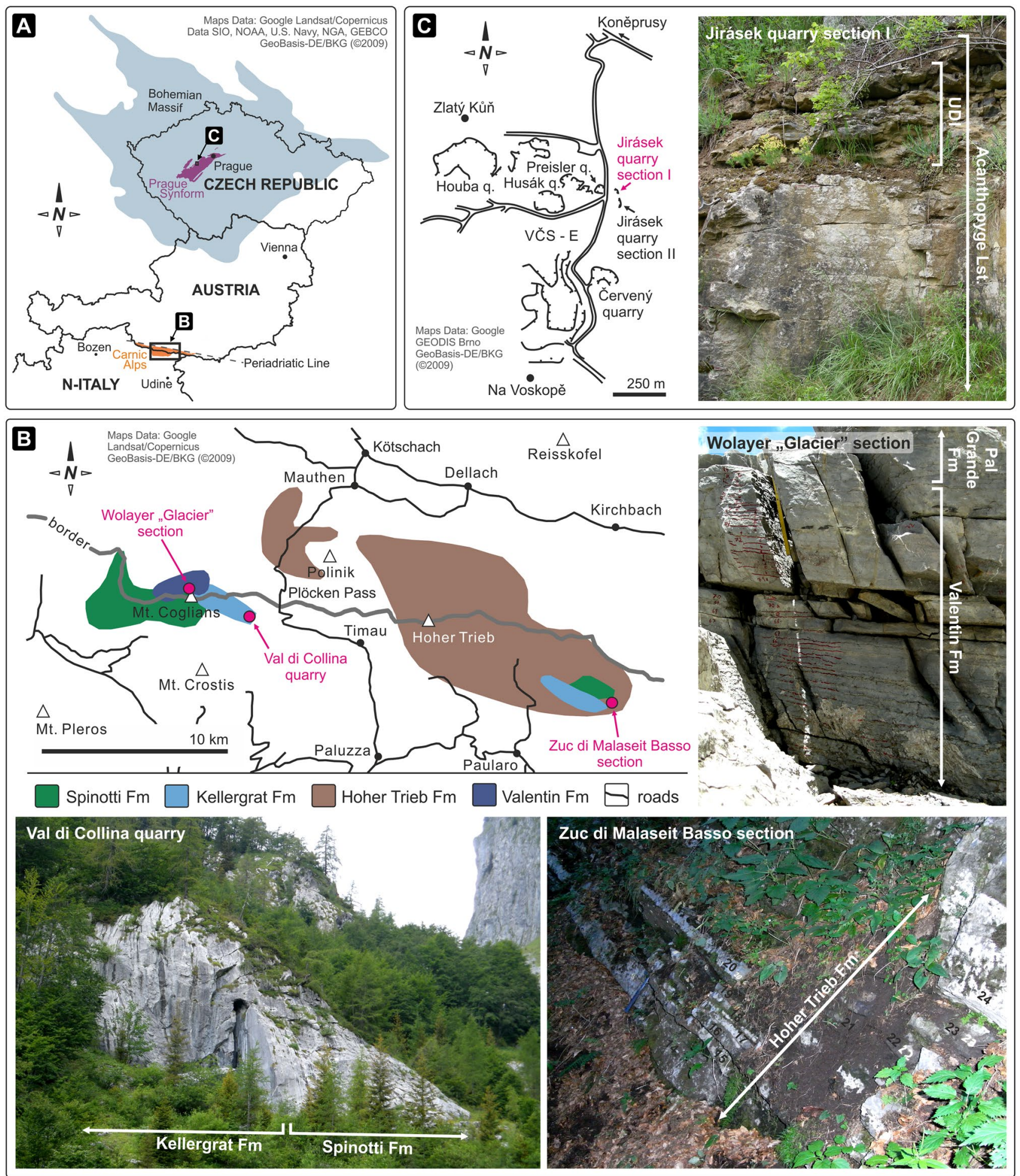

Figure 2. (A) Location of the Carnic Alps at the Austro-Italian border and the Prague Synform in Czech Republic. (B) Simplified map of the central Carnic Alps with areas of occurrence of the formations analysed in this paper. Investigated sections are the Wolayer "Glacier" section (Valentin Formation), the Val di Collina quarry (Spinotti and Kellergrat formations) and the Zuc di Malaseit Basso section (Hoher Trieb Formation). (C) Detailed map of the Koněprusy area with location of the Jirásek quarry section I and II. The photo left of the map shows the Upper Dark Interval (UDI) of the uppermost part of the Acanthopyge Limestone at Jirásek quarry section I. Maps in (A-C) designed in CorelDRAW ${ }^{\circ}$ X8 based on google earth images (maps data attribution incorporated within illustrations). 


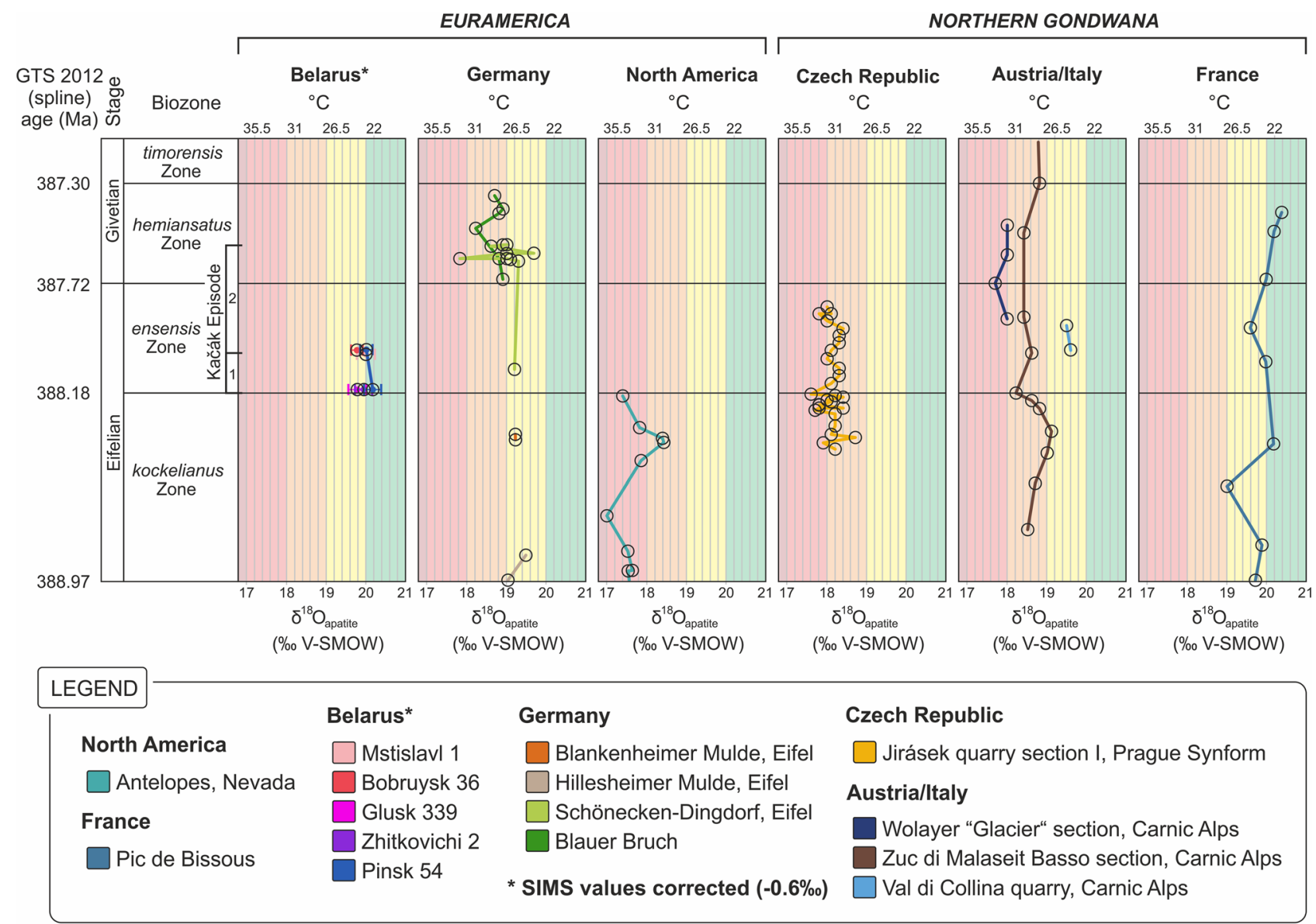

Figure 3. Comparison of $\delta^{18} \mathrm{O}_{\text {apatite }}$ isotope records during the late Eifelian and earliest Givetian (North-South sorted). Data from Belarus, Germany, North America and France compiled from Elrick et al. ${ }^{27}$, Joachimski et al. ${ }^{25}$, Königshof et al..$^{26}$ and Narkiewicz et al. ${ }^{28}$.

\section{Results}

In the Carnic Alps, the $\delta^{18} \mathrm{O}_{\text {apatite }}$ record of the $\mathrm{ZMB}$ section includes 11 measurements covering an interval between the lower part of the kockelianus Biozone (late Eifelian) and the entry of the timorensis Biozone (early Givetian). $\delta^{18} \mathrm{O}_{\text {apatite }}$ values are between 18.2 to $19.1 \%$ (VSMOW). Oxygen isotopes show a weak positive shift of $0.6 \%$ in the kockelianus Biozone, followed by a negative shift of $0.9 \%$ in the upper part of this biozone and gradually increasing to values of $18.8 \%$ at the hemiansatus/timorensis Biozone boundary (Fig. 3; Supplementary Fig. 1). Only few $\delta^{18} \mathrm{O}_{\text {apatite }}$ data were generated from shallow marine deposits due to the generally lower abundance of conodont elements. Samples from the Val di Collina quarry record only little variation during a short interval within the ensensis Biozone with values of 19.5 and 19.6\%o (Fig. 3; Supplementary Fig. 1). The condensed pelagic sequence of the Wolayer "Glacier" section yielded abundant conodonts, which were extracted from $\mathrm{cm}$-thick limestone levels separated along slightly uneven stylolite layers. $\delta^{18} \mathrm{O}_{\text {apatite }}$ values measured across the Eifelian-Givetian boundary vary between 17.7 and $18.0 \%$ (Fig. 3; Supplementary Fig. 1).

In the Prague Synform, the $\delta^{18} \mathrm{O}_{\text {apatite }}$ record at the Jirásek quarry section I includes 28 measurements covering the upper part of the kockelianus Biozone and most of the ensensis Biozone. Values range between 17.6 to $18.7 \%$ (VSMOW). The highest value of $18.7 \%$ is observed during the late kockelianus Biozone while the lowest value is observed before the entry of the ensensis Biozone (Fig. 3; Supplementary Fig. 1). Variations of about $1 \%$ are recognized within the sampled interval.

\section{Discussion}

For a better understanding of the paleotemperature record across the $\mathrm{E} / \mathrm{G}$ boundary, results from this study are compared with published $\delta^{18} \mathrm{O}_{\text {apatite }}$ values ${ }^{25-28}$ (Fig. 3). In total, 67 measurements are documented from the late Eifelian (kockelianus and ensensis biozones) and 21 values from the earliest Givetian (hemiansatus Biozone). The highest resolution is documented for the late Eifelian with $28 \delta^{18} \mathrm{O}_{\text {apatite }}$ values reported from the Prague Synform $\left(28^{\circ} \mathrm{S}\right)$. All data included in this study derive from localities allocated in southern hemisphere latitudes between $\sim 10-36^{\circ} \mathrm{S}$. In addition to the common approach used for paleotemperature calculation from $\delta^{18} \mathrm{O}_{\text {apatite, }}$, we applied a latitude-dependent correction for $\delta^{18} \mathrm{O}_{\text {seawater }}$ following the isotope-enabled ocean-atmosphere general circulation model of the National Aeronautics and Space Administration Goddard Institute for Space Studies (NASA GISS) ModelE- $\mathrm{R}^{38}$. The model provides better constraints on variations in $\delta^{18} \mathrm{O}_{\text {seawater }}$ as consequence 


\begin{tabular}{|c|c|c|c|c|c|c|c|c|c|c|}
\hline \multirow[b]{3}{*}{ Paleo-latitude } & \multirow[b]{3}{*}{ Country } & \multicolumn{9}{|c|}{ Paleotemperature estimates $\left(\delta^{18} \mathrm{O}_{\text {seawater }}=-1 \%\right.$ VSMOW $)$} \\
\hline & & \multicolumn{3}{|c|}{ Pre-/onset LEE1 } & \multicolumn{3}{|c|}{ LEE1-LEE2 } & \multicolumn{3}{|c|}{ Late/post-LEE2 } \\
\hline & & Min-max & Mean & $\mathbf{n}$ & Min-max & Mean & $\mathbf{n}$ & Min-max & Mean & $\mathbf{n}$ \\
\hline $10-14^{\circ} \mathrm{S}$ & Belarus & - & - & - & $22-24^{\circ} \mathrm{C}$ & $23^{\circ} \mathrm{C}$ & 6 & - & - & - \\
\hline $22^{\circ} \mathrm{S}$ & Germany $^{\mathrm{a}}$ & - & - & - & - & - & - & $28-31^{\circ} \mathrm{C}$ & $29^{\circ} \mathrm{C}$ & 6 \\
\hline $24^{\circ} \mathrm{S}$ & Germany $^{\mathrm{b}}$ & $25-27^{\circ} \mathrm{C}$ & $27^{\circ} \mathrm{C}$ & 4 & $27^{\circ} \mathrm{C}$ & $27^{\circ} \mathrm{C}$ & 1 & $24-33^{\circ} \mathrm{C}$ & $28^{\circ} \mathrm{C}$ & 9 \\
\hline $25^{\circ} \mathrm{S}$ & USA & $30-36^{\circ} \mathrm{C}$ & $33^{\circ} \mathrm{C}$ & 9 & - & - & - & - & - & - \\
\hline $28^{\circ} \mathrm{S}$ & Czech Republic & $29-34^{\circ} \mathrm{C}$ & $32^{\circ} \mathrm{C}$ & 16 & $30-33^{\circ} \mathrm{C}$ & $32^{\circ} \mathrm{C}$ & 12 & - & - & - \\
\hline $34^{\circ} \mathrm{S}$ & Austria & - & - & - & $32-33^{\circ} \mathrm{C}$ & $32^{\circ} \mathrm{C}$ & 2 & $32{ }^{\circ} \mathrm{C}$ & $32{ }^{\circ} \mathrm{C}$ & 2 \\
\hline $34^{\circ} \mathrm{S}$ & Italy $^{\mathrm{a}}$ & $27-31^{\circ} \mathrm{C}$ & $29^{\circ} \mathrm{C}$ & 7 & $29-30^{\circ} \mathrm{C}$ & $30^{\circ} \mathrm{C}$ & 2 & $30^{\circ} \mathrm{C}$ & $30^{\circ} \mathrm{C}$ & 1 \\
\hline $34^{\circ} \mathrm{S}$ & Italy $^{\mathrm{b}}$ & - & - & - & $25^{\circ} \mathrm{C}$ & $25^{\circ} \mathrm{C}$ & 2 & - & - & - \\
\hline $36^{\circ} \mathrm{S}$ & France & $22-27^{\circ} \mathrm{C}$ & $24^{\circ} \mathrm{C}$ & 4 & $23-25^{\circ} \mathrm{C}$ & $24^{\circ} \mathrm{C}$ & 2 & $21-23^{\circ} \mathrm{C}$ & $22^{\circ} \mathrm{C}$ & 3 \\
\hline Min-max & & $22-36^{\circ} \mathrm{C}$ & & & $22-33^{\circ} \mathrm{C}$ & & & $21-33^{\circ} \mathrm{C}$ & & \\
\hline Mean & & $27-31^{\circ} \mathrm{C}$ & $30^{\circ} \mathrm{C}$ & 40 & $27-28^{\circ} \mathrm{C}$ & $28^{\circ} \mathrm{C}$ & 27 & $27-30^{\circ} \mathrm{C}$ & $28^{\circ} \mathrm{C}$ & 21 \\
\hline Min-max ${ }^{*}$ & & $27-36^{\circ} \mathrm{C}$ & & & $29-33^{\circ} \mathrm{C}$ & & & $30-32{ }^{\circ} \mathrm{C}$ & & \\
\hline Mean* & & $28-34^{\circ} \mathrm{C}$ & $31^{\circ} \mathrm{C}$ & 32 & $27-32^{\circ} \mathrm{C}$ & $31^{\circ} \mathrm{C}$ & 16 & $29-31^{\circ} \mathrm{C}$ & $30^{\circ} \mathrm{C}$ & 9 \\
\hline
\end{tabular}

Table 1. Calculated regional paleotemperature ranges and mean values for each paleolatitude/country and biozone. Pre-/onset LEE1 = kockelianus Biozone; LEE1-LEE2 = ensensis Biozone; late/post-LEE2 = hemiansatus Biozone; Germany: $\mathrm{a}=$ Blauer Bruch, $\mathrm{b}=$ Eifel; Italy: $\mathrm{a}=\mathrm{ZMB}$ section, $\mathrm{b}=$ Val di Collina quarry; $\min -\mathrm{max}^{*}$ and mean ${ }^{\star}$ indicate calculation excluding shallow marine localities: Belarus, Germany ${ }^{\mathrm{b}}$, Italy ${ }^{\mathrm{b}}$ and France. Remark: Overall mean SST of the Carnic Alps (summarizing localities in Austria and Italy ${ }^{\mathrm{a}}$ ) are $31^{\circ} \mathrm{C}$ for the ensensis and hemiansatus biozones.

of latitude-dependent changes in the evaporation vs. precipitation ratio. A higher evaporation vs. precipitation ratio in the subtropics results in higher salinities and thus a higher $\delta^{18} \mathrm{O}_{\text {seawater }}$ whereas equatorial and higher latitudes are characterized by a lower $\delta^{18} \mathrm{O}_{\text {seawater }}$. We applied the correction published for the early Paleocene, a relatively warm time interval, likely comparable to the Devonian.

Paleotemperature estimates. For paleotemperature calculation, the phosphate-water isotope fractionation equation of Lécuyer et al. ${ }^{39}$ is used. Because no or at least no permanent glacial ice sheet was established around 388 million years ago ${ }^{40,41}$ and flooded continental area reached a maximum within the entire Phanerozoic record during the Middle Devonian ${ }^{42}$, a $\delta^{18} \mathrm{O}$ value of $-1 \%$ VSMOW for Middle Devonian seawater is assumed. As result, $\delta^{18} \mathrm{O}_{\text {apatite }}$ data from eastern and southern Euramerica indicate lower temperatures compared with localities from more southern latitudes on the western shelf of Euramerica and northern Gondwana. Depending on data availability, calculated mean $\delta^{18} \mathrm{O}_{\text {apatite }}$ values of each area from north to south show highest temperatures of $\sim 33^{\circ} \mathrm{C}$ on the western shelf of Euramerica around $25^{\circ} \mathrm{S}$ during the pre-/onset of the LEE1 (kockelianus Biozone), $\sim 32^{\circ} \mathrm{C}$ on the northern Gondwana shelf at $28^{\circ} \mathrm{S}$ during the LEE1-LEE2 interval (ensensis Biozone) and $\sim 31^{\circ} \mathrm{C}$ within offshore deposits at $34^{\circ} \mathrm{S}$ during the late/post-LEE2 (hemiansatus Biozone) (Table 1). Mean paleotemperatures during the pre-/onset of the LEE1 are $\sim 7^{\circ} \mathrm{C}$ higher in western Euramerica at $25^{\circ} \mathrm{S}$ than in southern Euramerica at $24^{\circ} \mathrm{S}$. The mean temperature difference between localities on the southern shelf of Euramerica $\left(24^{\circ} \mathrm{S}\right)$ and northern Gondwana $\left(28^{\circ} \mathrm{S}\right)$ during the LEE1-LEE2 interval is $5^{\circ} \mathrm{C}$. In the earliest Givetian (late/post-LEE2), the temperature offset between $24^{\circ} \mathrm{S}$ and $34^{\circ} \mathrm{S}$ decreases to $\sim 4^{\circ} \mathrm{C}$. However, a gradual latitudinal decrease in mean sea surface temperature is observed between 25 and $34^{\circ} \mathrm{S}$ during the late Eifelian and earliest Givetian Kačák Episode (Table 1).

Latitude correction for $\delta^{18} \mathrm{O}_{\text {seawater. }}$ Since the $\delta^{18} \mathrm{O}$ of seawater varies in part due to the evaporation to

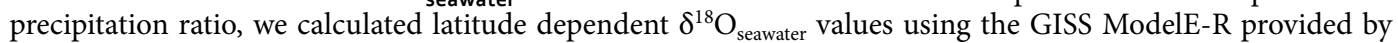
Roberts et al..$^{38}$ (Table 2). A comparison of both approaches (Tables 1 vs. 2 ) shows $\sim 2{ }^{\circ} \mathrm{C}$ higher temperatures when applying a latitude correction for $\delta^{18} \mathrm{O}_{\text {seawater }}$ (Fig. 4A-C; Supplementary Fig. 2). Hottest mean temperatures of $\sim 36^{\circ} \mathrm{C}$ at $25^{\circ} \mathrm{S}$ during the pre-/onset of the LEE1 (kockelianus Biozone), $\sim 34{ }^{\circ} \mathrm{C}$ at $28^{\circ} \mathrm{S}$ during the LEE1-LEE2 interval (ensensis Biozone) and $\sim 33^{\circ} \mathrm{C}$ at $34^{\circ} \mathrm{S}$ during the late/post-LEE2 (hemiansatus Biozone) were calculated using the data available for each biozone. Since SSTs from epeiric seas and continental margins are generally higher than average temperatures in the same latitude band ${ }^{43}$, we conclude that mean SSTs did not reach beyond $36^{\circ} \mathrm{C}$ within southern hemisphere low latitudes during the polyphased Kačák Episode (Table 2).

Uncertainties in the latitudinal paleotemperature record. High SSTs of Devonian low latitudes. A recently published Devonian climate simulation suggests a global annual mean surface air temperature of $21^{\circ} \mathrm{C}$ and tropical SST of $28^{\circ} \mathrm{C}$ for the Middle Devonian ${ }^{44}$. The model ${ }^{44}$ suggests colder low latitude mean SSTs compared to SSTs calculated from $\delta^{18} \mathrm{O}_{\text {apatite }}$ of Devonian conodonts. Combining the new $\delta^{18} \mathrm{O}_{\text {apatite }}$ data from the Prague Synform $\left(28^{\circ} \mathrm{S}\right)$ and the Carnic Alps ( $\left.34^{\circ} \mathrm{S}\right)$ with other published data (Supplementary Fig. 2), mean tropical-subtropical SSTs reach $33^{\circ} \mathrm{C}$ during late Eifelian/earliest Givetian time (Table 2: mean). However, Judd et al. ${ }^{43}$ call for caution when using paleotemperatures from shallow epeiric seas and continental margins as these 


\begin{tabular}{|c|c|c|c|c|c|c|c|c|c|c|c|}
\hline \multirow[b]{3}{*}{ Paleo-latitude } & \multirow[b]{3}{*}{ Country } & \multirow[b]{3}{*}{ Lat. corr. $\delta^{18} \mathrm{O}_{\text {seawater }}$} & \multicolumn{9}{|c|}{ Paleolatitude corrected paleotemperature estimates } \\
\hline & & & \multicolumn{3}{|c|}{ Pre-/onset LEE1 } & \multicolumn{3}{|c|}{ LEE1-LEE2 } & \multicolumn{3}{|c|}{ Late/post-LEE2 } \\
\hline & & & Min-max & Mean & $\mathbf{n}$ & Min-max & Mean & $\mathbf{n}$ & Min-max & Mean & $\mathbf{n}$ \\
\hline $10-14^{\circ} \mathrm{S}$ & Belarus & -0.70 to -0.63 & - & - & - & $25-26^{\circ} \mathrm{C}$ & $26^{\circ} \mathrm{C}$ & 6 & - & - & - \\
\hline $22^{\circ} \mathrm{S}$ & Germany $^{\mathrm{a}}$ & -0.53 & - & - & - & - & - & - & $31-34^{\circ} \mathrm{C}$ & $31{ }^{\circ} \mathrm{C}$ & 6 \\
\hline $24^{\circ} \mathrm{S}$ & Germany $^{\mathrm{b}}$ & -0.54 & $28-30^{\circ} \mathrm{C}$ & $29^{\circ} \mathrm{C}$ & 4 & $29^{\circ} \mathrm{C}$ & $29^{\circ} \mathrm{C}$ & 1 & $27-35^{\circ} \mathrm{C}$ & $30^{\circ} \mathrm{C}$ & 9 \\
\hline $25^{\circ} \mathrm{S}$ & USA & -0.54 & $33-39^{\circ} \mathrm{C}$ & $36^{\circ} \mathrm{C}$ & 9 & - & - & - & - & - & - \\
\hline $28^{\circ} \mathrm{S}$ & Czech Republic & -0.56 & $31-36^{\circ} \mathrm{C}$ & $34^{\circ} \mathrm{C}$ & 16 & $33-35^{\circ} \mathrm{C}$ & $34^{\circ} \mathrm{C}$ & 12 & - & - & - \\
\hline $34^{\circ} \mathrm{S}$ & Austria & -0.66 & - & - & - & $34-35^{\circ} \mathrm{C}$ & $35^{\circ} \mathrm{C}$ & 2 & $34^{\circ} \mathrm{C}$ & $34^{\circ} \mathrm{C}$ & 2 \\
\hline $34^{\circ} \mathrm{S}$ & Italy $^{\mathrm{a}}$ & -0.66 & $29-33^{\circ} \mathrm{C}$ & $31^{\circ} \mathrm{C}$ & 7 & $31-32{ }^{\circ} \mathrm{C}$ & $32{ }^{\circ} \mathrm{C}$ & 2 & $32^{\circ} \mathrm{C}$ & $32{ }^{\circ} \mathrm{C}$ & 1 \\
\hline $34^{\circ} \mathrm{S}$ & Italy $^{\mathrm{b}}$ & -0.66 & - & - & - & $27-28^{\circ} \mathrm{C}$ & $27^{\circ} \mathrm{C}$ & 2 & - & - & - \\
\hline $36^{\circ} \mathrm{S}$ & France & -0.70 & $24-30^{\circ} \mathrm{C}$ & $27^{\circ} \mathrm{C}$ & 4 & $25-27^{\circ} \mathrm{C}$ & $26^{\circ} \mathrm{C}$ & 2 & $24-25^{\circ} \mathrm{C}$ & $24^{\circ} \mathrm{C}$ & 3 \\
\hline \multicolumn{3}{|l|}{ Min-max } & $24-39^{\circ} \mathrm{C}$ & & & $25-35^{\circ} \mathrm{C}$ & & & $24-35^{\circ} \mathrm{C}$ & & \\
\hline \multicolumn{3}{|l|}{ Mean } & $29-33^{\circ} \mathrm{C}$ & $33^{\circ} \mathrm{C}$ & 40 & $29-30^{\circ} \mathrm{C}$ & $31^{\circ} \mathrm{C}$ & 27 & $30-32{ }^{\circ} \mathrm{C}$ & $30^{\circ} \mathrm{C}$ & 21 \\
\hline \multicolumn{3}{|l|}{$\operatorname{Min}-\max ^{*}$} & $29-39^{\circ} \mathrm{C}$ & & & $31-35^{\circ} \mathrm{C}$ & & & $32-34^{\circ} \mathrm{C}$ & & \\
\hline \multicolumn{3}{|l|}{ Mean $^{\star}$} & $31-36^{\circ} \mathrm{C}$ & $34^{\circ} \mathrm{C}$ & 32 & $33-34^{\circ} \mathrm{C}$ & $34^{\circ} \mathrm{C}$ & 16 & $33^{\circ} \mathrm{C}$ & $32^{\circ} \mathrm{C}$ & 9 \\
\hline
\end{tabular}

Table 2. Paleolatitude corrected regional paleotemperature including the latitude correction values for $\delta^{18} \mathrm{O}_{\text {seawater }}$ and mean values calculated for each paleolatitude/country and biozone. Pre-/onset LEE1 = kockelianus Biozone; LEE1-LEE2 = ensensis Biozone; late/post-LEE2 = hemiansatus Biozone; Germany: $\mathrm{a}=$ Blauer Bruch, $\mathrm{b}=$ Eifel; Italy: $\mathrm{a}=\mathrm{ZMB}$ section, $\mathrm{b}=$ Val di Collina quarry; min-max ${ }^{\star}$ and mean ${ }^{\star}$ calculated excluding shallow marine localities: Belarus, Germany ${ }^{\mathrm{b}}$, Italy ${ }^{\mathrm{b}}$ and France. Lat. corr. $=$ latitude correction. Overall mean SST of the Carnic Alps (summarizing localities in Austria and Italy ${ }^{\mathrm{a}}$ ) are $33^{\circ} \mathrm{C}$ for the ensensis and hemiansatus biozones.

are systematically higher compared to open-ocean temperatures from the same latitude band and thus result in an overestimation of global mean temperatures. Though, it seems a paradox, that especially conodonts from epeiric Belarus $\left(10-14^{\circ} \mathrm{S}\right)$, the Eifel area $\left(24^{\circ} \mathrm{S}\right)$, shallow marine platform deposits of the Carnic Alps $\left(34^{\circ} \mathrm{S}\right)$ and from Pic de Bissous ( $36^{\circ} \mathrm{S}$ ) indicate significantly lower paleotemperatures compared to those from slope and offshore deposits. A possible explanation could be an interval of arid climate conditions in tropical-subtropical realms linked with the Kačák Episode which led to increased evaporation in shallow shelf areas and thus higher $\delta^{18} \mathrm{O}_{\text {apatite }}$ values due to regionally increased salinity.

Zonal heterogeneity of low latitude SSTs. $\quad \delta^{18} \mathrm{O}_{\text {apatite }}$ from the epeiric sea of eastern Euramerica $\left(10-14^{\circ} \mathrm{S}\right)$ and shallow marine deposits of southern Euramerica $\left(24^{\circ} \mathrm{S}\right)$ exhibit higher values which compare better with values of conodonts from northern Gondwana at $34-36^{\circ} \mathrm{S}$ rather than with those from more open marine settings between 25 and $34^{\circ} \mathrm{S}$ at least during the late Eifelian (Fig. 3, Supplementary Fig. 2). This could be explained by regional salinity variations as suggested for localities between 10 and $14^{\circ} \mathrm{S}^{28,29}$ or upwelling of colder intermediate waters in the Rheic Ocean ${ }^{45-48}$.

SSTs modelled for the Middle Devonian ${ }^{44}$ give significantly lower SSTs along the southern hemisphere Euramerican shelf compared to temperature estimates for open ocean settings of the same latitude. According to the Holocene SST record, a highest temperature of $32^{\circ} \mathrm{C}$ (central equatorial Indian Ocean) and a lowest temperature of $17^{\circ} \mathrm{C}$ (eastern equatorial Atlantic) between 0 and $5^{\circ} \mathrm{S}$ are documented ${ }^{49}$. As indicated by modern sea surface temperatures ${ }^{50}$, SST of low latitude waters does not always show a gradational temperature decrease towards higher latitudes. Hence, temperature variations within the low latitude belt like those documented in $\delta^{18} \mathrm{O}_{\text {apatite }}$ from Euramerican shallow shelf localities between 10 and $24^{\circ} \mathrm{S}$ likely reflect, similar to present day SSTs, regional factors as for example evaporation, runoff via large river delta systems, submarine groundwater discharge, karst water flow in coastal areas, ocean circulation, or upwelling zones along continental shelfs.

Mean SST record across the Eifelian/Givetian boundary. The interpretation of the paleotemperature trend across the Eifelian/Givetian boundary is difficult, because of the low number of isotope values available. Data of only two localities, at $34^{\circ} \mathrm{S}$ (ZMB section, Italy) and $36^{\circ} \mathrm{S}$ (Pic de Bissous sections, France), span the entire interval from the kockelianus until the hemiansatus Biozone. Additionally, $\delta^{18} \mathrm{O}_{\text {apatite }}$ values from the epeiric Belarusian Basin $\left(10-14^{\circ} \mathrm{S}\right)^{28,29}$, as well as those derived from conodonts of shallow marine deposits at $24^{\circ} \mathrm{S}^{25,26}, 34^{\circ} \mathrm{S}$ (this study, Supplementary Fig. 2) and $36^{\circ} \mathrm{S}^{25}$ are higher compared to values from conodonts of coeval more open marine habitats, contradicting expected values in relation to the latitudinal allocation. $\delta^{18} \mathrm{O}_{\text {apatite }}$ values of the three localities from different depositional settings within the Carnic Alps at $34^{\circ} \mathrm{S}$, for example, differ significantly. Local conditions could have been responsible for such high zonal heterogeneity of SST. While the shallow marine carbonate platform setting (Val di Collina section) might have been affected by higher evaporation translating into higher $\delta^{18} \mathrm{O}_{\text {seawater }}$ and thus higher $\delta^{18} \mathrm{O}_{\text {apatite }}$ values, conodonts from pelagic deposits (Wolayer "Glacier" section) show lowest $\delta^{18} \mathrm{O}_{\text {apatite }}$ values likely reflecting normal-marine more open ocean salinity and temperature. This documents that $\delta^{18} \mathrm{O}_{\text {apatite }}$ values obtained from conodonts of tropical-subtropical shallow marine settings may not only represent seawater temperature but as well local salinity variations, as noted by 
A

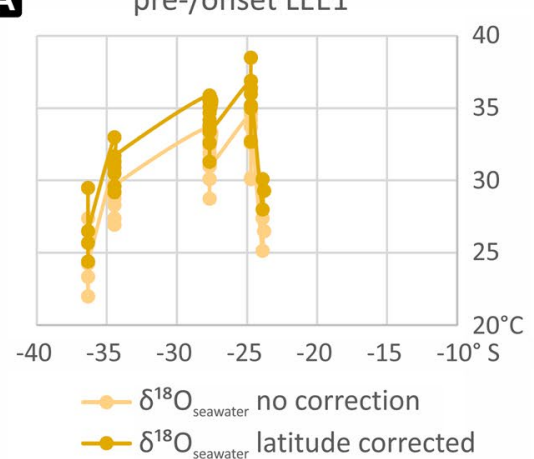

D

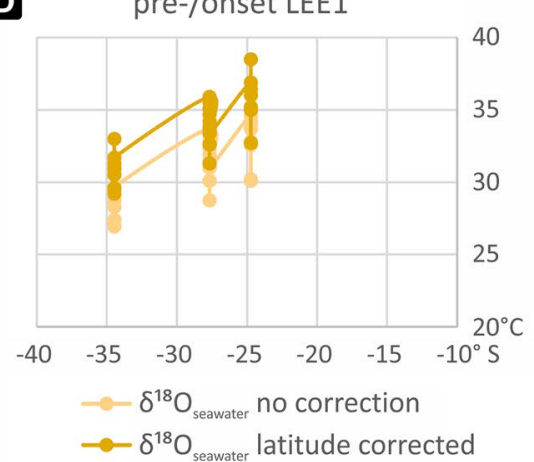

B

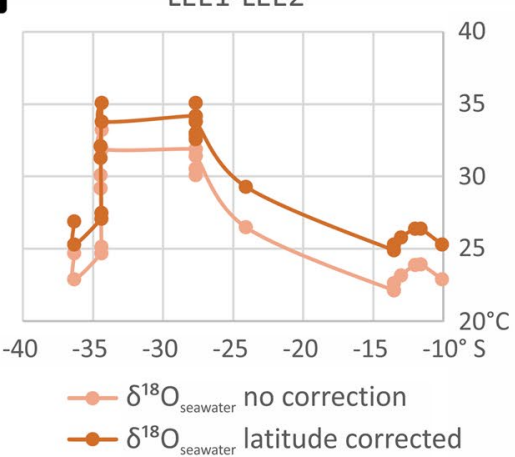

C

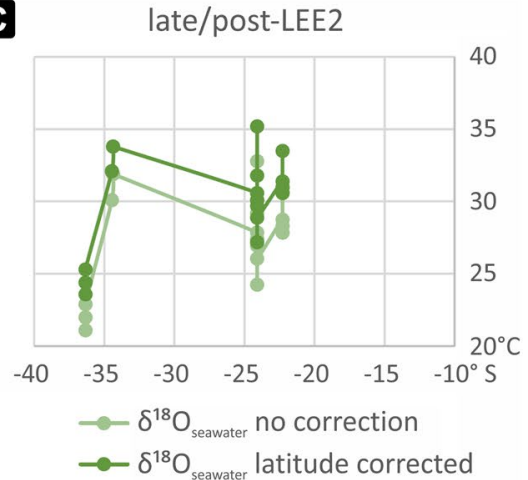

$\mathbf{E}$

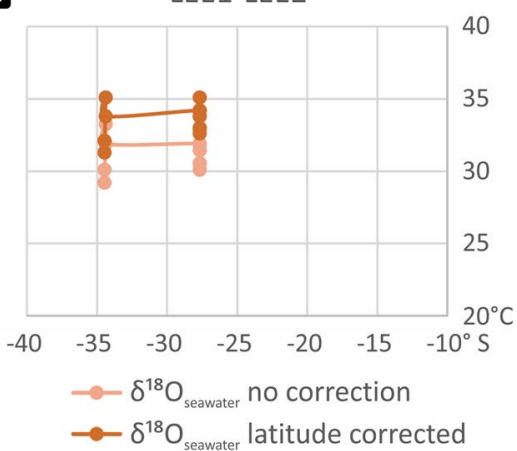

$\mathbf{F}$

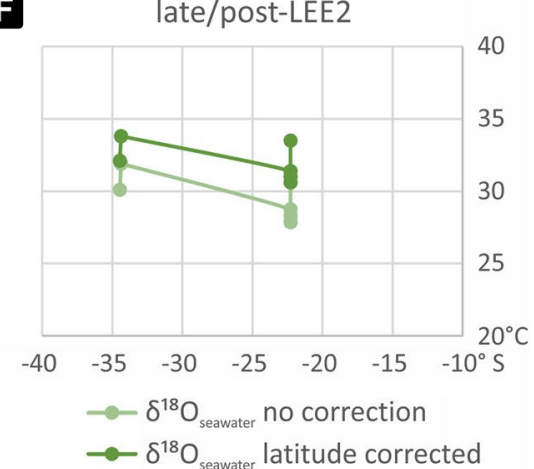

Figure 4. Comparison of paleotemperatures calculated from $\delta^{18} \mathrm{O}_{\text {apatite }}$ assuming $\delta^{18} \mathrm{O}_{\text {seawater }}=-1 \%$ VSMOW vs. applying a latitude correction for $\delta^{18} \mathrm{O}_{\text {seawater }}$ during the (A,D) pre-/onset LEE1 (kockelianus Biozone), (B,E) LEE1-LEE2 (ensensis Biozone) and (C,F) late/post-LEE2 (hemiansatus Biozone). (A-C) Entire dataset. (D-F) Shallow marine localities excluded. $\mathrm{x}$-axis: southern hemisphere latitude; $\mathrm{y}$-axis: temperature in ${ }^{\circ} \mathrm{C}$.

several studies on $\delta^{18} \mathrm{O}_{\text {apatite }}$ before $\mathrm{e}^{25,27-29,43,51,52}$. Thus, exclusively $\delta^{18} \mathrm{O}_{\text {apatite }}$ data from more open marine settings are used for calculation of mean paleotemperature. This results in higher mean SST as observed especially for mean SST calculated for the LEE1-LEE2 interval (ensensis Biozone), with a significant increase in temperatures from $\sim 31{ }^{\circ} \mathrm{C}$ to $\sim 34{ }^{\circ} \mathrm{C}$ (Table 2: mean vs. mean ${ }^{\star}$ ). In summary, our data argue for at least $6{ }^{\circ} \mathrm{C}$ higher mean SST across the Kačák Episode compared to published model estimates suggesting mean values of $28^{\circ} \mathrm{C}$ for the tropical-subtropical climate belt ${ }^{44}$.

Additionally, more open marine sections at $25-34^{\circ} \mathrm{S}$ show slightly decreasing mean SST from north to south during each biozone-interval (Fig. $4 \mathrm{~A}-\mathrm{C}$ vs. D-F, Table 2). A mean latitudinal temperature gradient of $\sim 5^{\circ} \mathrm{C}$ between 25 and $34^{\circ} \mathrm{S}$ is observed for the pre-/onset LEE1 interval (kockelianus Biozone) which is somewhat higher compared to the present day mean temperature gradient of $\sim 4.5^{\circ} \mathrm{C}$ for the same latitudinal range $e^{43}$. Calculating a mean latitudinal temperature gradient between 28 and $34^{\circ} \mathrm{S}$, a decrease from $\sim 3{ }^{\circ} \mathrm{C}$ during the pre-/onset LEE1 (kockelianus Biozone) to $\sim{ }^{\circ} \mathrm{C}$ during the LEE1-LEE2 (ensensis Biozone) is observed (compare Fig. 4D-E). The present-day mean latitudinal temperature gradient between 28 and $34^{\circ} \mathrm{S}$ is $\sim 3.3^{\circ} \mathrm{C}^{43}$. Thus, we argue that global warming resulted in a minor latitudinal SST gradient in the subtropics and probably slightly higher latitudes that may have had an important effect for marine biota. Specifically, climate sensitive organisms like corals and stromatoporoids could spread more easily towards higher latitudes along broad shelfs. Hence, we suggest that the Kačák Episode could have triggered the early-middle Givetian acme of coral distribution and diversity.

\section{Conclusion}

The main results of this study can be summarized as follows:

- New conodont $\delta^{18} \mathrm{O}_{\text {apatite }}$ data around the Kačák Episode (late Eifelian to earliest Givetian) from the Carnic Alps $\left(34^{\circ} \mathrm{S}\right)$ and the Prague Synform $\left(28^{\circ} \mathrm{S}\right)$ indicate mean SSTs between 31 and $34^{\circ} \mathrm{C}$.

- SST of late Eifelian southern hemisphere low latitudes was at least $6^{\circ} \mathrm{C}$ higher than previously assumed.

- $\delta^{18} \mathrm{O}_{\text {apatite }}$ based paleotemperatures from conodonts of tropical-subtropical shallow water should only be used with great caution, confirming previous studies suggesting that salinity variations may affect the oxygen isotope values.

- Global warming caused a flattening of the latitudinal temperature gradient in the subtropics and probably as well higher latitudes having an important effect for marine biota. 
- Specifically, climate sensitive organisms could spread more easily towards higher latitudes along broad shelfs. Hence, we suggest that the Kačák Episode could have triggered the early-middle Givetian acme of coral and stromatoporoid distribution and diversity.

\section{Materials and methods}

Conodont extraction. Conodont elements were extracted from limestones using 5\% formic acid (Carnic Alps 2013, 2015; Prague Synform 2013) and 6\% acetic acid (Prague Synform 2020) diluted in 5 L buckets filled with tap water. In order to prevent dissolution of conodont elements, the acid was exchanged twice a day until the carbonates were completely dissolved (generally after 7-10 days). In case of large amounts of insoluble residues, heavy liquid separation was applied at room temperature (sodium polytungstate; density: $2.79 \mathrm{~g} / \mathrm{cm}^{3}$ ). The colour alteration index (CAI) of the conodont elements from the Carnic Alps is 4-5 and 5 (Supplementary Fig. 3) which agrees well with earlier observations of Brime et al. ${ }^{53}$, who published a comprehensive conodont CAI study of the Carnic Alps. Conodonts from the Jirásek quarry (Prague Synform) have a CAI of 3 (Supplementary Fig. 3).

Repository. Conodont elements from the Carnic Alps are stored at the Geological Survey of Austria in Vienna, Austria (Wolayer "Glacier" section: GBA-2016/013/0001-0018; Val di Collina quarry: GBA2016/015/0001-0015) and at the Museo Friulano di Storia Naturale in Udine, Italy (ZMB section: MFSNgp 48161-48222). Conodont elements from the Prague Synform are stored at the Czech Geological Survey (Jirásek quarry section I and II: SV1-SV121). Permission was obtained from repository holding Institutions for the use of conodont materials included within this study.

Oxygen isotope analyses. Two analytical methodologies, thermal conversion-elemental analyser-isotope ratio mass spectrometry (TC-EA IRMS) and secondary ionization mass spectrometry (SIMS) are commonly used for measuring oxygen isotopes on biogenic apatite. While the first technique measures the oxygen isotopic composition of the $\mathrm{PO}_{4}$ group of several conodont specimens ${ }^{25}$, SIMS enables a high-resolution spot analysis, but measures $\delta^{18} \mathrm{O}$ of total oxygen $\left(\mathrm{PO}_{4}{ }^{3-}, \mathrm{CO}_{3}{ }^{2-}\right.$ and $\left.\mathrm{OH}^{-}\right)$of single conodont elements ${ }^{54}$. Oxygen isotopes of bioapatite (conodont crown tissue without basal tissue preserved) within this study were analysed by TC-EA IRMS using a ThermoFinnigan Delta V Plus mass spectrometer at the Geozentrum Nordbayern (FAU ErlangenNürnberg, Germany). Depending on the amount of trisilverphosphate precipitated after dissolving conodont apatite in $\mathrm{HNO}_{3}$, triplicate measurements were conducted whenever possible. Values are reported in \%o relative to VSMOW. The standard deviation of replicate sample analyses was \pm 0.02 to \pm 0.34 ( $1 \sigma$; see Supplementary Fig. 1). NBS $120 \mathrm{c}$ was measured as $21.7 \%$. Literature based SIMS values and TC-EA IRMS values that are calibrated with standards other than NBS 120c (21.7\%o) were corrected for direct comparison (see Supplementary Fig. $\left.2:-0.7 \% 0^{25} ;-0.9 \% 0^{27} ;-0.6 \%{ }^{28}\right)$. For paleotemperature calculation, the phosphate-water isotope fractionation equation of Lécuyer et al. ${ }^{39}$ is used: $\mathrm{T}\left({ }^{\circ} \mathrm{C}\right)=117.4( \pm 9.5)-4.50( \pm 0.43)\left(\delta^{18} \mathrm{O}_{\text {apatite }}-\delta^{18} \mathrm{O}_{\text {seawater }}\right)$ assuming $\delta^{18} \mathrm{O}$ of Devonian seawater as $-1 \%$ VSMOW.

Stratigraphic correlation of $\delta^{18} \mathrm{O}_{\text {apatite }}$ records. Biostratigraphically constrained $\delta^{18} \mathrm{O}_{\text {apatite }}$ values from the Carnic Alps ${ }^{11}$, the Prague Synform ${ }^{18}$ and the Blankenheim section of the Eifel area ${ }^{26}$ are correlated within biozonal boundary ranges via high-resolution magnetic susceptibility and geochemical data. Published data of other sections from Germany and from France ${ }^{25}$ are plotted according to the absolute age ${ }^{25}$ and correlated via conodont biozone boundaries ${ }^{55-58}$. Data from North America ${ }^{27}$ are correlated with the ZMB section of the Carnic Alps ${ }^{11}$ via the australis/kockelianus biozone boundary and the upper limit of the T-R cycle Id (calibrated to $393.37 \mathrm{Ma})^{11}$. Data published from Belarus ${ }^{28}$ are biostratigraphically constrained by conodonts to the ensensis Biozone and were already combined within the standard-corrected data of Joachimski et al. ${ }^{25}$.

Calculation of latitude dependent $\delta^{18} \mathrm{O}$ of seawater. Seawater $\delta^{18} \mathrm{O}$ is dependent on the ratio evaporation vs. precipitation which is higher in subtropical latitudes relative to equatorial and higher latitudes. The calculation of spatial gradients in $\delta^{18} \mathrm{O}_{\text {seawater }}$ follows Roberts et al. ${ }^{38}$, which prerequisites exact paleolatitude calculation for each locality. Since the climate conception of an ice-free Middle Devonian ${ }^{40,42}$ compares better $^{2}$ with early Paleogene climate conditions rather than with preindustrial climates, we adopted latitude-dependent seawater $\delta^{18} \mathrm{O}$ estimates for the early Paleogene ${ }^{38}$.

Paleolatitude calculation. The calculation of paleolatitudinal positions for the various areas follows Scotese and Wright ${ }^{59}$ (Supplementary Fig. 2). Evaluation of the tectonic setting around Val di Collina quarry ${ }^{53}$ results in a slightly more southern paleolatitudinal position than suggested by Scotese and Wright ${ }^{59}$. In general, the paleo-position is calculated to a latitudinal precision of $1^{\circ}$, based on the equation used.

\section{Data availability}

All data of this study are provided in the paper and Supplementary Information.

Received: 14 May 2021; Accepted: 3 August 2021

Published online: 16 August 2021 


\section{References}

1. Walliser, O. H. The Eifelian-Givetian stage boundary. Cour. Forsch.-Inst. Senck. 225, 37-47 (2000).

2. Johnson, J. G., Klapper, G. \& Sandberg, C. A. Devonian eustatic fluctuations in Euramerica. Geol. Soc. Am. Bull. 96, 567-587 (1985).

3. Chlupáč, I. \& Kukal, Z. Possible global events and the stratigraphy of the Palaeozoic of the Barrandian (Cambrian-Middle Devonian), Czechoslovakia. Sbor. Geol. Věd. Geol. 43, 83-146 (1988).

4. Hladil, J. \& Kalvoda, J. Extinction and recovery successions of the Devonian marine shoals: Eifelian-Givetian and Frasnian-Famenian events Moravia and Bohemia. Věst. Čes. Geol. Úst. 68, 13-23 (1993).

5. House, M. R. The Middle Devonian Kačák Event. Proceedings of the Ussher Society 9, 79-84 (1996).

6. House, M. R. Strength, timing, setting and cause of mid-Palaeozoic extinctions. Palaeogeogr. Palaeoclimatol. Palaeoecol. 181, 5-25 (2002).

7. Hladíková, J., Hladil, J. \& Kř́bek, B. Carbon and oxygen isotope record across the Pridoli to Givetian stage boundaries in the Barrandian basin (Czech Republic). Palaeogeogr. Palaeoclimatol. Palaeoecol. 132, 225-241 (1997).

8. Hladil, J. et al. Stratigraphic variation of complex impurities in platform limestones and possible significance of atmospheric dust: A study with emphasis on gamma-ray spectrometry and magnetic susceptibility outcrop logging (Eifelian-Frasnian, Moravia, Czech Republic). Int. J. Earth Sci. 95, 703-723 (2006).

9. van Hengstum, P. \& Gröcke, D. R. Stable-isotope record of the Eifelian-Givetian boundary Kačák-otomari Event (Middle Devonian) from Hungry Hollow, Ontario, Canada. Can. J. Earth Sci. 45, 353-366 (2008).

10. Walliser, O. H. \& Bultynck, P. Extinctions, survival and innovations of conodont species during the Kačák Episode (Eifelian-Givetian) in south-eastern Morocco. Bulletin de l'Institut royal des Siences naturelles de Belgique, Sciences de la Terre 81, 5-25 (2011).

11. Suttner, T. J. et al. Conodont diversity across the Late Eifelian Kačák Episode of the southern Alpine realm (central Carnic Alps, Austria/Italy). Palaeogeogr. Palaeoclimatol. Palaeoecol. 479, 34-47 (2017).

12. Ellwood, B. B., Algeo, T. J., El Hassani, A., Tomkin, J. H. \& Rowe, H. D. Defining the timing and duration of the Kačák Interval within the Eifelian/Givetian boundary GSSP, Mech Irdane, Morocco, using geochemical and magnetic susceptibility patterns. Palaeogeogr. Palaeoclimatol. Palaeoecol. 304, 74-84 (2011).

13. Ellwood, B. B., El Hassani, A., Tomkin, J. H. \& Bultynck, P. A climate-driven model using time-series analysis of magnetic susceptibility (x) datasets to represent a floating-point high-resolution geological timescale for the Middle Devonian Eifelian stage. In Magnetic Susceptibility Application: A Window onto Ancient Environments and Climatic Variations (eds Da Silva, A. C. et al.) 209-223 (Geological Society London Special Publications 414, 2015).

14. House, M. R. Correlation of mid-Palaeozoic ammonoid evolutionary events with global sedimentary perturbations. Nature 213, 17-22 (1985).

15. Becker, R. T. \& Kullmann, J. Paleozoic ammonoids in space and time. In Ammonoid Paleobiology. Volume 13 of Topics in Geobiology (eds Landman, N. et al.) 711-753 (Plenum Press, 1996).

16. Korn, D. \& Klug, C. Palaeozoic ammonoids-diversity and development of conch morphology. In Earth and Life, International Year of Planet Earth (ed. Talent, J. A.) 491-534 (Springer Science + Business Media B.V., 2012).

17. Weddige, K. Die Conodonten der Eifel-Stufe im Typusgebiet und in benachbarten Faziesgebieten. Senck. Leth. 58, 271-419 (1977).

18. Vodrážková, S. \& Suttner, T. J. Middle Devonian (Eifelian) conodonts of the australis-ensensis zones from the Jirásek quarry near Koněprusy (Barrandian area, Czech Republic) with special emphasis on Polygnathus pseudofoliatus Group and notes on environmental changes related to the Kačák Episode. Bull. Geosci. 95, 81-125 (2020).

19. Chlupáč, I. Devonian trilobites-Evolution and events. Geobios 27, 487-505 (1994).

20. Budil, P. \& Mergl, M. Trilobite assemblage of Calceola-bearing beds in Acanthopyge Limestone (Choteč Formation, Middle Devonian, Eifelian, Prague Basin, the Czech Republic). Foss. Impr. 75, 79-91 (2019).

21. Walliser, O. H. Natural boundaries and commission boundaries in the Devonian. Cour. Forsch.-Inst. Senck. 75, 401-408 (1985).

22. Suttner, T. J., Kido, E. \& Suttner, A. W. W. Icriodus marieae, a new icriodontid conodont species from the Middle Devonian. Paläontol. Z. 91, 137-144 (2017).

23. Jamart, V. \& Denayer, J. The Kačák event (late Eifelian, Middle Devonian) on the Belgian shelf and its effects on rugose coral palaeobiodiversity. Bull. Geosci. 95, 279-311 (2020).

24. Mergl, M. \& Budil, P. Rhynchonelliform brachiopods and trilobites of the 'upper dark interval' in the Koněprusy area (Devonian, Eifelian, Kačák Event; the Czech Republic). Foss. Impr. 75, 92-107 (2019).

25. Joachimski, M. M. et al. Devonian climate and reef evolution: Insights from oxygen isotopes in apatite. Earth Planet. Sci. Lett. 284, 599-609 (2009).

26. Königshof, P., Da Silva, A.-C., Suttner, T. J., Kido, E., Waters, J., Carmichael, S., Jansen, U., Pas, D. \& Spassov, S. Shallow-water facies setting around the Kačák Event: A multidisciplinary approach. In Devonian Climate, Sea-Level and Evolutionary Events (eds Becker, R. T. et al.) 171-199 (Geological Society London Special Publications 423, 2016).

27. Elrick, M. et al. Stratigraphic and oxygen isotope evidence for My-scale glaciation driving eustasy in the Early-Middle Devonian greenhouse world. Palaeogeogr. Palaeoclimatol. Palaeoecol. 276, 170-181 (2009).

28. Narkiewicz, M., Narkiewicz, K., Krzemińska, E. \& Kruchek, S. A. Oxygen isotopic composition of conodont apatite in the equatorial eiperic Belarussian Basin (Eifelian)-Relationship to fluctuating seawater salinity and temperature. Palaios 32, 439-447 (2017).

29. Narkiewicz, M. et al. Late Eifelian Kačák Episode in the epeiric Belarusian Basin: Role of terrestrial-marine teleconnections. Palaeogeogr. Palaeoclimatol. Palaeoecol. 562, 110106 (2021).

30. Kiessling, W. Paleoclimatic significance of Phanerozoic reefs. Geology 29, 751 (2001).

31. Copper, P. Silurian and Devonian reefs: 80 million years of global greenhouse between two ice ages. SEPM Spec. Publ. 72, 181-238 (2002).

32. Jakubowicz, M. et al. At the southern limits of the Devonian reef zone: Palaeoecology of the Aferdou el Mrakib reef (Givetian, eastern Anti-Atlas, Morocco). Geol. J. 54, 10-38 (2019).

33. Scotese, C. R. An atlas of paleogeographic maps: The seas come in and the seas go out. Annu. Rev. Earth Planet. Sci. 49, 669-718 (2021).

34. Kreutzer, L. H., Schönlaub, H. P. \& Hubmann, B. The Devonian of Austria. In IGCP-421 Inaugural Meeting Vienna, Guidebook, vol. 40 (ed. Schönlaub, H. P.) 42-60 (Berichte der Geologischen Bundesanstalt, 1997).

35. Corradini, C. \& Suttner, T. J. (eds) The Pre-Variscan Sequence of the Carnic Alps (Austria and Italy) Vol. 69 (Abh. Geol. Bundesanst, 2015).

36. Chlupáč, I., Havlíček, V., Kř́žž, J., Kukal, Z. \& Štorch, P. Palaeozoic of the Barrandian (Cambrian to Devonian) (Czech Geological Survey, 1998).

37. Budil, P. Demonstrations of the Kačák event (Middle Devonian, uppermost Eifelian) at some Barrandian localities. Věstn. Česk. Geol. Úst. 70, 1-19 (1995).

38. Roberts, C. D., LeGrande, A. N. \& Tripati, A. K. Sensitivity of seawater oxygen isotopes to climatic and tectonic boundary conditions in an early Paleogene simulation with GISS ModelE-R. Paleoceanography 26, PA4203 (2011).

39. Lécuyer, C., Amiot, R., Touzeau, A. \& Trotter, J. Calibration of the phosphate $\delta^{18} \mathrm{O}$ thermometer with carbonate-water oxygen isotope fractionation equations. Chem. Geol. 347, 217-226 (2013).

40. Cao, W. et al. Palaeolatitudinal distribution of lithologic indicators of climate in a palaeogeographic framework. Geol. Mag. 156, 331-354 (2019). 
41. Scotese, C. R., Song, H., Mills, B. J. W. \& van der Meer, D. G. Phanerozoic paleotemperatures: The earth's changing climate during the last 540 million years. Earth-Sci. Rev. 215, 1-47 (2021).

42. Cao, W. et al. Improving global paleogeography since the late Paleozoic using paleobiology. Biogeosciences 14, 5425-5439 (2017).

43. Judd, E. J., Bhattacharya, T. \& Ivany, L. C. A dynamical framework for interpreting ancient sea surface temperatures. Geophys. Res. Lett. 47, 1-10 (2020).

44. Brugger, J., Hofmann, M., Petri, S. \& Feulner, G. On the sensitivity of the Devonian climate to continental configuration, vegetation cover, orbital configuration, $\mathrm{CO}_{2}$ concentration, and insolation. Paleoceanogr. Paleoclimatol. 34, 1375-1398 (2019).

45. Oczlon, M. S. Ocean currents and unconformities: The North Gondwana Middle Devonian. Geology 18, 509-512 (1990).

46. Hüneke, H. Erosion and deposition from bottom currents during the Givetian and Frasnian: Response to intensified oceanic circulation between Gondwana and Laurussia. Palaeogeogr. Palaeoclimatol. Palaeoecol. 234, 146-167 (2006).

47. Hüneke, H. Pelagic carbonate ooze reworked by bottom currents during Devonian approach of the continents Gondwana and Laurussia. In Economic and Palaeoceanographic Significance of Contourite Deposits, vol. 276 (eds Viana, A. R. \& Rebesco, M.) 299-328 (Geological Society London Special Publications, 2007).

48. Crasquin, S. \& Horne, D. J. The palaeopsychrosphere in the Devonian. Lethaia 51, 547-563 (2018),

49. Zachos, J. C., Stott, L. D. \& Lohnmann, K. C. Evolution of early Cenozoic marine temperatures. Paleoceanography 9, 353-387 (1994).

50. NOAA (National Oceanic and Atmospheric Administration), Climate Prediction Center GIS Portal (2018). http://www.cpc.ncep. noaa.gov/products/GODAS/. Accessed 05 Sept 2018.

51. Elrick, M. et al. Orbital-scale climate change and glacioeustasy during the early Late Ordovician (pre-Hirnantian) determined from $\delta^{18} \mathrm{O}$ values in marine apatite. Geology 41, 775-778 (2013).

52. Montañez, I. P. \& Poulsen, C. J. The Late Paleozoic Ice Age: An evolving paradigm. Annu. Rev. Earth Planet. Sci. 41, 629-656 (2013).

53. Brime, C., Perri, M. C., Pondrelli, M., Spalletta, C. \& Venturini, C. Polyphase metamorphism in the eastern Carnic Alps (N Italy-S Austria): Clay minerals and conodont colour alteration index evidence. Int. J. Earth Sci. 97, 1213-1229 (2008).

54. Trotter, J. A., Williams, I. S., Barnes, C. R., Lécuyer, C. \& Nicoll, R. S. Did cooling oceans trigger Ordovician biodiversification? Evidence from conodont thermometry. Science 321, 550-554 (2008).

55. Gradstein, F. M. et al. (eds) A Geologic Time Scale 2004589 (Cambridge University Press, 2005).

56. Ogg, J. G. et al. (eds) The Concise Geologic Time Scale (Cambridge University Press, 2008).

57. Ogg, J. G. \& Ogg, G. Paleozoic Time Scale and Sea-Level History (Chart, ICS, 2008).

58. Gradstein, F. et al. (eds) The Geological Time Scale 20121144 (Elsevier, 2012).

59. Scotese, C. R. \& Wright, N. M. PALEOMAP Paleodigital Elevation Models (PaleoDEMS) for the Phanerozoic PALEOMAP Project (2018). https://www.earthbyte.org/paleodem-resource-scotese-and-wright-2018/. Accessed 17 Aug 2020

\section{Acknowledgements}

E.K. and T.J.S. kindly thank the Austrian Science Fund for financial support (Project: FWF P23775-B17). S.V. and M.K. acknowledge the Czech Geological Survey for funding (project no. 310430, DKRVO2018-2022, part 2: Research on biodiversity and global changes in geological history). Daniele Lutz (GeoZentrum Nordbayern, Erlangen) is thanked for preparation of conodont material for oxygen isotope analysis. We are grateful to Christopher R. Scotese (PALEOMAP Project, Illinois) for providing an updated version of his Eifelian paleomap. This study is a contribution to the DAGGER project coordinated by Sarah Carmichael and Johnny Waters (both Appalachian State University, NC) and to IGCP 652. Two anonymous reviewer and Przemyslaw Gorzelak (handling editor) are thanked for constructive comments on an earlier version of the manuscript. Shivani Choudhary (editorial support) and Urvashi Raina (editorial assistant) are kindly thanked for technical support during the submission process.

\section{Author contributions}

T.J.S. and E.K. initiated and designed this study and prepared a first manuscript draft. M.M.J. provided the methodological background and carried out oyxgen isotope analysis for this research work. All authors contributed to this work with their force during fieldwork (T.J.S., E.K., S.V., M.P., C.C., M.G.C., L.S.), bio-/stratigraphic correlation (T.J.S., C.C., M.G.C., S.V., M.P., L.S.), geochemical analyses (M.M.J., E.K., S.V., M.K.) and in writing the manuscript text (T.J.S., E.K., M.M.J., S.V., C.C., M.P., M.G.C., L.S.).

\section{Competing interests}

The authors declare no competing interests.

\section{Additional information}

Supplementary Information The online version contains supplementary material available at https://doi.org/ 10.1038/s41598-021-96013-3.

Correspondence and requests for materials should be addressed to T.J.S.

Reprints and permissions information is available at www.nature.com/reprints.

Publisher's note Springer Nature remains neutral with regard to jurisdictional claims in published maps and institutional affiliations.

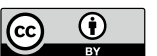

Open Access This article is licensed under a Creative Commons Attribution 4.0 International License, which permits use, sharing, adaptation, distribution and reproduction in any medium or format, as long as you give appropriate credit to the original author(s) and the source, provide a link to the Creative Commons licence, and indicate if changes were made. The images or other third party material in this article are included in the article's Creative Commons licence, unless indicated otherwise in a credit line to the material. If material is not included in the article's Creative Commons licence and your intended use is not permitted by statutory regulation or exceeds the permitted use, you will need to obtain permission directly from the copyright holder. To view a copy of this licence, visit http://creativecommons.org/licenses/by/4.0/.

(c) The Author(s) 2021 